Jurnal Ilmu Ilmu Agribisnis: Journal of Agribusiness Science, 9(4), November 2021

\title{
PENDAPATAN USAHATANI TEBU RAKYAT DAN POLA KEMITRAAN PADA PETANI MITRA PT BUMA CIMA NUSANTARA, KABUPATEN LAMPUNG UTARA
}

\author{
(Sugar Cane Farming Income Analysis and Partnership Pattern of PT Buma Cima Nusantara \\ Partner Farmers, North Lampung Regency)
}

Safira Puspa Nusa, Dwi Haryono, Yuliana Saleh

\begin{abstract}
Jurusan Agribisnis, Fakultas Pertanian, Universitas Lampung, J1. Prof. Dr. Soemantri Brojonegoro No. 1 Bandar Lampung 35145,e-mail: dwi.haryono@fp.unila.ac.id
\end{abstract}

\begin{abstract}
The objectives of this research were to find out the income of sugar cane farming and the implement of partnership pattern between PT Buma Cima Nusantara and partner farmers in Bunga Mayang Sub-District, North Lampung Regency. The location was determined purposively, considering that Bunga Mayang SubDistrict has been the center of sugar cane production in North Lampung Regency. The number of respondents in this research were 66 respondents and taken randomly. Data were collected from January to February 2020. The analytical methods that used were farm income analysis and descriptive qualitative analysis. The study shows that the average income for total cost of sugar cane farming is $R p 12,056,030.40 /$ hectare and the $R / C$ ratio is 1.49. The partnership pattern that PT Buma Cima Nusantara and partner farmers implemented is a agribusiness operational cooperation partnership pattern, where the sugar cane farmers act as a group of partners that provide land, facilities, and labors and PT Buma Cima Nusantara acts as a partner company that provides costs, capital, management, procurement of production facilities, and the guarantor of the product market.
\end{abstract}

Key words: income, partnership, sugar cane farming

Received: 26 June $2020 \quad$ Revised:14 August $2020 \quad$ Accepted:31 August $2020 \quad$ DOI: http://dx.doi.org/10.23960/jiia.v9i4.5398

\section{PENDAHULUAN}

Salah satu komoditi perkebunan yang mempunyai peran strategis dalam perekonomian di Indonesia, yaitu tebu. Tebu sebagai bahan baku industri gula merupakan salah satu sumber pendapatan bagi ribuan petani tebu dan pekerja di industri gula. Gula adalah salah satu komoditas pertanian yang telah ditetapkan Indonesia sebagai komoditas khusus (special product) dalam forum perundingan Organisasi Perdagangan Dunia (WTO), bersama beras, jagung dan kedelai. Indonesia berupaya meningkatkan produksi gula dalam negeri, termasuk mencanangkan target swasembada gula dengan pertimbangan utama untuk memperkuat ketahanan pangan dan kualitas hidup di pedesaan (Arifin 2008).

Menurut Direktorat Jenderal Perkebunan (2018), Provinsi Lampung merupakan provinsi dengan produksi dan luas areal tebu terbesar kedua di Indonesia. Hal tersebut dapat dilihat dari kontribusi Provinsi Lampung terhadap jumlah keseluruhan produksi tebu Indonesia, yaitu sebesar 29,91 persen dan sebesar 27,72 persen luas areal tebu Indonesia dimiliki oleh Provinsi Lampung.
Salah satu kabupaten di Provinsi Lampung yang menjadi sentra produksi tebu perkebunan rakyat adalah Kabupaten Lampung Utara. Kabupaten Lampung Utara merupakan kabupaten dengan tingkat produksi tebu perkebunan rakyat terbesar ketiga di Provinsi Lampung.

Salah satu kecamatan yang menjadi sentra produksi tebu rakyat di Kabupaten Lampung Utara adalah Kecamatan Bunga Mayang. Hal tersebut dikarenakan pada tahun 2016, sebesar 89,29 persen luas areal tebu rakyat di Kabupaten Lampung Utara dimiliki oleh Kecamatan Bunga Mayang. Tetapi, pada lima tahun terakhir produktivitas hablur tebu rakyat di Kecamatan Bunga Mayang cenderung menurun (PT Buma Cima Nusantara 2019). Besarnya luas areal tebu rakyat yang dimiliki oleh Kecamatan Bunga Mayang, seharusnya dapat menghasilkan tingkat produksi dan produktivitas yang tinggi. Tinggi atau rendahnya tingkat produktivitas mempengaruhi pendapatan petani tebu rakyat di Kecamatan Bunga Mayang.

PT Buma Cima Nusantara merupakan satu-satunya pabrik gula yang berada di Kabupaten Lampung 
Utara, tepatnya di Kecamatan Bunga Mayang. Sebelumnya, PT Buma Cima Nusantara merupakan unit usaha yang berada di bawah manajemen PT Perkebunan Nusantara VII yang bernama PT Perkebunan Nusantara VII Distrik Bunga Mayang, namun kini PT Buma Cima Nusantara telah menjadi anak perusahaan dan terpisah manajemen dengan PT Perkebunan Nusantara VII. PT Buma Cima Nusantara merupakan perkebunan besar negara yang mengadakan program kemitraan dengan petani tebu rakyat (perkebunan rakyat), sehingga petani tebu rakyat yang berada di Kecamatan Bunga Mayang menjual hasil panennya ke pabrik gula tersebut.

Menurut Pranoto, Lestari, dan Murniati (2017), ketepatan pembayaran hasil panen atau bagi hasil dari pihak PT Perkebunan Nusantara VII Distrik Bunga Mayang kepada petani masih perlu ditingkatkan. Hal tersebut menimbulkan pertanyaan, apakah setelah PT Buma Cima Nusantara terpisah manajemen dengan PT Perkebunan Nusantara VII pola kemitraan yang dilaksanakan masih sama atau tidak. Berdasarkan uraian tersebut, maka tujuan dari penelitian ini adalah menganalisis pendapatan usahatani tebu rakyat dan menganalisis pola kemitraan yang dilaksanakan antara PT Buma Cima Nusantara dengan petani tebu mitra di Kecamatan Bunga Mayang, Kabupaten Lampung Utara.

\section{METODE PENELITIAN}

Penentuan lokasi penelitian dilakukan secara sengaja (purposive sampling) dengan pertimbangan bahwa pada tahun 2016, sebesar 89,29 persen luas areal tebu rakyat di Kabupaten Lampung Utara dimiliki oleh Kecamatan Bunga Mayang, tetapi pada lima tahun terakhir produktivitas hablur tebu rakyat di Kecamatan Bunga Mayang cenderung menurun. Berdasarkan jumlah petani tebu mitra terbanyak, maka dipilihlah dua desa secara sengaja sebagai lokasi penelitian, yaitu Desa Mulyorejo II dan Desa Isorejo.

Responden penelitian ini adalah petani tebu rakyat yang bermitra dengan PT Buma Cima Nusantara di Kecamatan Bunga Mayang. Penentuan petani responden dilakukan dengan menggunakan metode pengambilan sampel secara acak berstrata (stratified random sampling) dan secara acak sederhana (simple random sampling). Pengambilan sampel dilakukan dengan cara membagi populasi ke dalam kelompok-kelompok homogen yang disebut dengan strata terlebih dahulu, yaitu petani PC, kepras I, kepras II, dan kepras III, kemudian sampel diambil secara acak sederhana dari setiap strata yang ada.

Penentuan jumlah sampel menggunakan rumus yang merujuk pada teori (Sugiarto dkk 2003) sebagai berikut:

$\mathrm{n}=\frac{\mathrm{NZ}}{\mathrm{Nd}^{2}+\mathrm{s}^{2}}$

$$
\begin{aligned}
& \text { Keterangan: } \\
& \mathrm{n} \quad \text { = Jumlah sampel petani tebu rakyat } \\
& \mathrm{N} \quad \text { = Jumlah populasi petani tebu rakyat } \\
& \mathrm{Z} \quad=\text { Tingkat kepercayaan }(95 \%=1,96) \\
& \mathrm{S}^{2} \quad=\text { Varian sampel }(5 \%=0,05) \\
& \mathrm{d} \quad=\text { Derajat penyimpangan }(5 \%=0,05)
\end{aligned}
$$

Berdasarkan Nazir (1988), ditentukan alokasi proporsi sampel untuk jumlah petani di masingmasing desa dengan rumus berikut:

$\mathrm{na}=\frac{\mathrm{N}_{\mathrm{a}}}{\mathrm{N}_{\mathrm{ab}}} \times \mathrm{n}_{\mathrm{ab}}$

\section{Keterangan:}

na $=$ Jumlah sampel petani

$\mathrm{n}_{\mathrm{ab}}=$ Jumlah sampel keseluruhan

$\mathrm{N}_{\mathrm{a}}$ = Jumlah populasi petani

$\mathrm{N}_{\mathrm{ab}}=$ Jumlah populasi petani keseluruhan

Berdasarkan jumlah sampel petani di masingmasing desa, ditentukan proporsi sampel berdasarkan umur tanaman dengan rumus yang sama, sehingga didapat jumlah sampel dari petani tebu PC, kepras I, kepras II, dan kepras III di Desa Mulyorejo II berturut-turut adalah tiga orang, enam orang, sembilan orang, dan empat orang. Jumlah sampel dari petani tebu PC, kepras I, kepras II, dan kepras III di Desa Isorejo berturut-turut adalah enam orang, sepuluh orang, sebelas orang, dan tujuh belas orang. Total petani sampel adalah 66 orang. Waktu pengumpulan data dilakukan pada bulan Januari 2020-Februari 2020.

Data yang digunakan dalam penelitian ini adalah data primer yang diperoleh dari petani tebu rakyat sebagai responden melalui teknik wawancara dengan menggunakan kuesioner dan data sekunder yang diperoleh dari studi literatur serta lembagalembaga atau instansi terkait, seperti Badan Pusat Statistik (BPS), Direktorat Jenderal Perkebunan, Kementerian Pertanian, dan PT Buma Cima Nusantara. 
Metode pengumpulan data yang digunakan dalam penelitian ini adalah metode survei. Metode analisis data yang digunakan adalah analisis kuantitatif untuk menganalisis pendapatan usahatani tebu rakyat dan analisis deskriptif kualitatif untuk mengetahui pola kemitraan yang dilaksanakan antara PT Buma Cima Nusantara dengan petani tebu mitra di Kecamatan Bunga Mayang, Kabupaten Lampung Utara.

Pendapatan merupakan selisih antara penerimaan dengan biaya total yang dikeluarkan untuk usahatani tebu dalam satu musim tanam. Pendapatan dirumuskan sebagai berikut (Soekartawi 2002):

Pendapatan $=\mathrm{TR}-\mathrm{TC}$

Keterangan:

$\mathrm{TR}=$ Total Revenue $($ penerimaan total $)(\mathrm{Rp})$

$\mathrm{TC}=$ Total Cost (biaya total) $(\mathrm{Rp})$

Total Revenue (TR) atau penerimaan total merupakan hasil perkalian antara jumlah hasil produksi dalam satu musim tanam dengan harga jual gula dan tetes. Penerimaan total dirumuskan sebagai berikut (Soekartawi 2002):

$\mathrm{TR}=\mathrm{Q} \times \mathrm{P}$

Keterangan:

$\mathrm{TR}=$ Total Revenue $($ penerimaan total $)(\mathrm{Rp})$

$\mathrm{Q}=$ Jumlah hasil panen $(\mathrm{kg})$

$\mathrm{P} \quad=$ Harga jual $(\mathrm{Rp} / \mathrm{kg})$

Total Cost (TC) atau biaya total merupakan penjumlahan dari biaya tetap dan biaya variabel, mencakup seluruh biaya untuk usahatani tebu selama satu musim tanam. Biaya total dirumuskan sebagai berikut (Soekartawi 2002):

$\mathrm{TC}=\mathrm{FC}+\mathrm{VC}$

Keterangan:

$\mathrm{TC}=$ Total Cost $($ biaya total $)(\mathrm{Rp})$

$\mathrm{FC}=$ Fixed Cost (biaya tetap) (Rp)

$\mathrm{VC}=$ Variable Cost (biaya variabel) $(\mathrm{Rp})$

Analisis Revenue Cost Ratio (R/C Ratio) merupakan perbandingan antara penerimaan dengan biaya untuk menilai kelayakan usahatani. Analisis Revenue Cost Ratio (R/C Ratio) dirumuskan sebagai berikut (Soekartawi 2002):

$\mathrm{R} / \mathrm{C}$ Ratio $=\frac{\mathrm{TR}}{\mathrm{TC}}$
Keterangan:

$\mathrm{R} / \mathrm{C}$ Ratio $=$ Nisbah penerimaan dan biaya

$\mathrm{TR}=$ Total Revenue $($ penerimaan total) (Rp)

TC = Total Cost (biaya total) $(\mathrm{Rp})$

Kriteria kelayakan usahatani tebu untuk R/C Ratio, yaitu:

a. Jika R/C Ratio > 1, maka usahatani tebu menguntungkan dan layak untuk dilaksanakan, karena penerimaan lebih besar dari biaya.

b. Jika R/C Ratio < 1, maka usahatani tebu merugikan dan tidak layak untuk dilaksanakan, karena penerimaan lebih kecil dari biaya.

c. Jika R/C Ratio $=1$, maka usahatani tebu berada pada kondisi impas, karena penerimaan sama dengan biaya.

Analisis deskriptif kualitatif melihat bagaimana pola kemitraan yang dilaksanakan antara PT Buma Cima Nusantara dengan petani tebu mitra di Kecamatan Bunga Mayang, Kabupaten Lampung Utara. Penentuan bentuk atau pola kemitraan, berdasarkan lima bentuk kemitraan dalam sistem agribisnis di Indonesia menurut Sumardjo, Sulaksana, dan Darmono (2004). Lima bentuk kemitraan tersebut, yaitu pola kemitraan intiplasma, pola kemitraan subkontrak, pola kemitraan dagang umum, pola kemitraan keagenan, dan pola kemitraan kerjasama operasional agribisnis (KOA). Analisis ini juga melihat bagaimana pelaksanaan kredit kemitraan, pelayanan yang diberikan PT Buma Cima Nusantara kepada petani mitra, penjualan gula dan tetes, hak dan kewajiban petani mitra, hak dan kewajiban pabrik gula, serta kendala dalam pelaksanaan program kemitraan.

\section{HASIL DAN PEMBAHASAN}

\section{Kondisi Umum Responden}

Mayoritas usia petani responden berada pada kelompok usia 45-64 tahun dengan persentase sebesar 51,52 persen. Hal tersebut menunjukkan bahwa petani tebu rakyat di Kecamatan Bunga Mayang berada pada kelompok usia produktif. Mayoritas tingkat pendidikan petani responden adalah Sekolah Dasar (SD) dengan persentase sebesar 43,94 persen. Sebagian besar petani responden memiliki pengalaman berusahatani tebu 11-20 tahun dengan persentase sebesar 39,39 persen.

Sebesar 53,03 persen petani responden tidak memiliki mata pencaharian sampingan. Hal tersebut menunjukkan bahwa sebagian besar petani 
responden hanya mengandalkan usahatani tebu sebagai mata pencaharian pokok mereka. Sebesar 65,15 persen petani responden memiliki jumlah tanggungan keluarga sebanyak 1-2 jiwa. Mayoritas status kepemilikan lahan petani responden adalah milik sendiri dengan luas lahan sedang (0,5-2 ha). Sebesar 54,55 persen petani responden menggunakan bibit tebu varietas $\mathrm{BM}$ 9044 dan sebesar 45,45 persen menggunakan varietas BM 9605.

Petani responden menjalankan usahatani tebu rakyat dengan menggunakan modal pinjaman. Pinjaman modal tersebut berasal dari bank yang kemudian akan disalurkan oleh pihak PT Buma Cima Nusantara kepada petani mitra (avalis off taker). Pinjaman modal yang diberikan berupa biaya perawatan, biaya saprodi, dan biaya tebang muat angkut (TMA). Pihak yang selama ini aktif memberikan penyuluhan pertanian kepada petani tebu rakyat di Kecamatan Bunga Mayang adalah PT Buma Cima Nusantara. Mayoritas petani responden mengikuti penyuluhan pertanian sebanyak 1-2 kali (31,82\% dan 37,88\%).

\section{Analisis Pendapatan Usahatani Tebu Rakyat}

Analisis pendapatan usahatani tebu rakyat dibagi menjadi lima berdasarkan umur tanaman yaitu tebu
PC, kepras I, kepras II, kepras III, dan gabungan. Analisis pendapatan usahatani tebu rakyat di Kecamatan Bunga Mayang dapat dilihat pada Tabel 1.

Berdasarkan Tabel 1, rata-rata pendapatan per hektar tertinggi petani tebu rakyat di Kecamatan Bunga Mayang ada pada tebu kriteria kepras I, yaitu Rp20.981.148,24 untuk pendapatan atas biaya tunai dan Rp13.529.763,29 untuk pendapatan atas biaya total. Hal tersebut dikarenakan pada kriteria kepras I tidak terdapat biaya bibit maupun biaya pengolahan lahan seperti pada kriteria PC dan produksi tebu pada kriteria kepras I merupakan produksi tebu tertinggi. Rata-rata pendapatan per hektar terendah ada pada tebu kriteria PC, yaitu Rp14.562.798,38 untuk pendapatan atas biaya tunai dan Rp7.413.260,45 untuk pendapatan atas biaya total. Hasil penelitian ini selaras dengan hasil penelitian Apriawan, Irham, dan Mulyo (2015) yang menyatakan bahwa pendapatan tertinggi dari produksi gula dan tetes di PT Perkebunan Nusantara VII (Persero) Distrik Bunga Mayang adalah pada tebu kriteria kepras I.

Nilai R/C rasio tertinggi ada pada usahatani tebu kriteria kepras I, yaitu 2,16 untuk nilai $\mathrm{R} / \mathrm{C}$ rasio atas biaya tunai dan 1,55 untuk nilai $\mathrm{R} / \mathrm{C}$ rasio atas biaya

total.

Tabel 1. Analisis pendapatan usahatani tebu rakyat di Kecamatan Bunga Mayang

\begin{tabular}{|c|c|c|c|c|c|}
\hline Uraian & $\mathrm{PC}$ & Kepras I & Kepras II & Kepras III & Gabungan \\
\hline Per usahatani & 1,56 ha & 2,03 ha & 1,93 ha & 2,73 ha & 2,16 ha \\
\hline Penerimaan & $63.190 .506,93$ & $82.830 .803,63$ & $75.820 .809,18$ & $105.903 .825,86$ & $85.369 .756,77$ \\
\hline Biaya Tunai & $39.589 .634,22$ & $38.347 .587,15$ & $35.874 .367,73$ & $51.613 .631,73$ & $41.867 .476,87$ \\
\hline Biaya Diperhitungkan & $11.153 .279,17$ & 15.126.311,46 & $14.424 .723,13$ & 18.974.020,63 & $15.596 .202,90$ \\
\hline Total Biaya & $50.742 .913,39$ & $53.473 .898,61$ & $50.299 .090,85$ & 70.207.259,51 & $57.463 .679,77$ \\
\hline Total Potongan $*$ ) & $36.869 .123,11$ & $34.534 .162,15$ & $31.883 .705,23$ & $44.657 .369,83$ & $37.270 .417,78$ \\
\hline Pendapatan Kotor A. B. Tunai & $15.079 .165,88$ & $33.385 .620,41$ & $30.282 .794,39$ & $42.439 .983,54$ & $32.829 .969,11$ \\
\hline Biaya Insentif & $882.907,24$ & $1.891 .485,55$ & 1.687.216,71 & $2.435 .196,20$ & $1.865 .051,34$ \\
\hline Pendapatan Bersih A. B. Tunai & $22.717 .965,47$ & $42.591 .730,93$ & $38.259 .224,73$ & $52.235 .390,79$ & 41.637.228,57 \\
\hline Pendapatan Bersih A. B. Total & $11.564 .686,30$ & $27.465 .419,48$ & $23.834 .501,61$ & $33.261 .370,15$ & $26.041 .025,66$ \\
\hline R/C Rasio A. B. Tunai & 1,60 & 2,16 & 2,12 & 2,07 & 2,04 \\
\hline R/C Rasio A. B. Total & 1,25 & 1,55 & 1,51 & 1,51 & 1,49 \\
\hline \multicolumn{6}{|l|}{ Per hektar } \\
\hline Penerimaan & $40.506 .735,21$ & $40.803 .351,54$ & $39.285 .393,36$ & $38.792 .610,21$ & $39.523 .035,54$ \\
\hline Biaya Tunai & $25.377 .970,65$ & $18.890 .437,02$ & $18.587 .755,30$ & $18.766 .754,17$ & 19.383.091,14 \\
\hline Biaya Diperhitungkan & $7.149 .537,93$ & $7.451 .384,95$ & $7.473 .949,81$ & $6.950 .190,71$ & $7.220 .464,31$ \\
\hline Total Biaya & $32.527 .508,58$ & 26.341.821,98 & $26.061 .705,11$ & $25.716 .944,88$ & $26.603 .555,45$ \\
\hline Total Potongan *) & $23.634 .053,27$ & $17.011 .902,54$ & $16.520 .054,52$ & 16.358.010,93 & $17.254 .823,05$ \\
\hline Pendapatan Kotor A. B. Tunai & $9.666 .131,98$ & $16.446 .118,43$ & $15.690 .567,04$ & $15.545 .781,52$ & 15.199.059,78 \\
\hline Biaya Insentif & $565.966,18$ & $931.766,28$ & $874.205,55$ & $892.013,26$ & $863.449,69$ \\
\hline Pendapatan Bersih A. B. Tunai & $14.562 .798,38$ & $20.981 .148,24$ & $19.823 .432,50$ & $19.133 .842,78$ & 19.276.494,71 \\
\hline Pendapatan Bersih A. B. Total & 7.413.260,45 & $13.529 .763,29$ & $12.349 .482,70$ & 12.183.652,07 & $12.056 .030,40$ \\
\hline R/C Rasio A. B. Tunai & 1,60 & 2,16 & 2,12 & 2,07 & 2,04 \\
\hline R/C Rasio A. B. Total & 1,25 & 1,55 & 1,51 & 1,51 & 1,49 \\
\hline
\end{tabular}

Sumber: Data primer, 2020 (data diolah)

Keterangan: A. B. = singkatan dari Atas Biaya

*) Total potongan hanya digunakan untuk perhitungan biaya insentif 
Nilai R/C rasio terendah ada pada usahatani tebu kriteria $\mathrm{PC}$, yaitu 1,60 untuk nilai $\mathrm{R} / \mathrm{C}$ rasio atas biaya tunai dan 1,25 untuk nilai $\mathrm{R} / \mathrm{C}$ rasio atas biaya total.per hektar dan nilai $\mathrm{R} / \mathrm{C}$ rasio usahatani tebu kriteria kepras I lebih besar dibandingkan dengan kriteria lainnya.

Tebu seluruh kriteria merupakan gabungan dari tebu kriteria PC, kepras I, kepras II, dan kepras III. Dilakukannya perhitungan tebu gabungan ini diharapkan dapat menggambarkan usahatani tebu rakyat di Kecamatan Bunga Mayang secara keseluruhan. Berdasarkan Tabel 1, rata-rata pendapatan per hektar petani tebu rakyat seluruh kriteria di Kecamatan Bunga Mayang adalah Rp19.276.494,71 untuk pendapatan atas biaya tunai dan Rp12.056.030,40 untuk pendapatan atas biaya total. Hasil penelitian ini tidak jauh berbeda dengan hasil penelitian Agiesta, Widjaya, dan Hasanuddin (2017) yang menyatakan bahwa pendapatan usahatani tebu per hektar per musim tanam petani mitra PT Gunung Madu Plantations di Kabupaten Lampung Tengah sebesar Rp11.403.828,63.

Nilai R/C rasio usahatani tebu seluruh kriteria lebih besar dari 1, hal ini menunjukkan bahwa usahatani tebu rakyat di Kecamatan Bunga Mayang menguntungkan dan layak untuk diusahakan, karena penerimaan lebih besar dari biaya. Nilai $\mathrm{R} / \mathrm{C}$ rasio atas biaya tunai sebesar 2,04 artinya setiap Rp1,00 biaya tunai yang dikeluarkan petani tebu rakyat dalam usahatani tebu, akan menghasilkan penerimaan sebesar Rp2,04. Nilai $R / C$ rasio atas biaya total sebesar 1,49 artinya setiap $\mathrm{Rp} 1,00$ biaya total yang dikeluarkan petani tebu rakyat dalam usahatani tebu, akan menghasilkan penerimaan sebesar Rp1,49.

Berdasarkan hasil penelitian yang telah dilakukan oleh Sakinah, Hasyim, dan Suryani (2019) mengenai pendapatan usahatani tebu petani mitra mandiri PT Pemuka Sakti Manis Indah di Kabupaten Way Kanan, diperoleh nilai R/C atas biaya tunai pada petani tebu mitra mandiri biaya, mandiri partial kontrak, dan murni masing-masing yaitu $3,80,3,34$, dan 3,58 , sedangkan nilai $\mathrm{R} / \mathrm{C}$ atas biaya total masing-masing yaitu 3,23, 3,04, dan 3,08. Hal tersebut menunjukkan bahwa usahatani tebu petani mitra mandiri PT Pemuka Sakti Manis Indah di Kabupaten Way Kanan lebih menguntungkan, jika dibandingkan dengan usahatani tebu rakyat petani mitra PT Buma Cima Nusantara di Kecamatan Bunga Mayang, Kabupaten Lampung Utara.
Tinggi atau rendahnya pendapatan petani tebu rakyat di Kecamatan Bunga Mayang dipengaruhi oleh beberapa faktor, seperti jumlah produksi, rendemen, dan lain-lain. Rata-rata produksi tebu per hektar seluruh kriteria petani tebu rakyat di Kecamatan Bunga Mayang adalah 79,60 ton/ha. Menurut Badan Litbang Pertanian (2007), produktivitas tebu rata-rata di tingkat petani berkisar antara 60-70 ton/ha, idealnya lebih dari 100 ton/ha. Hal tersebut menunjukkan bahwa ratarata produktivitas tebu per hektar petani tebu rakyat di Kecamatan Bunga Mayang belum mencapai tingkat produktivitas ideal.

Rata-rata produksi tebu per hektar tertinggi petani tebu rakyat di Kecamatan Bunga Mayang ada pada tebu kriteria kepras I. Hasil penelitian ini selaras dengan hasil penelitian Gustiana (2017) dan Pranoto dkk (2017) yang menyatakan bahwa ratarata produksi tebu per hektar tertinggi ada pada tebu kriteria kepras I. Hal tersebut dikarenakan jumlah populasi tebu tertinggi berada pada kepras I dan akan mengalami penurunan pada keprasan berikutnya, akibat dari adanya dinamika populasi.

Menurut Supriyadi (1992), tinggi rendahnya produksi gula yang dihasilkan, tergantung pada besar kecilnya rendemen tebu yang dihasilkan. Rata-rata rendemen tebu pada usahatani tebu rakyat di Kecamatan Bunga Mayang seluruh kriteria adalah 6,73 persen. Tinggi rendahnya kadar gula atau rendemen dipengaruhi oleh tiga faktor, yaitu faktor budidaya (on farm), faktor tebang angkut, dan faktor pengolahan (off farm).

Berdasarkan hasil penelitian, sebesar 56,06 persen petani tebu rakyat di Kecamatan Bunga Mayang tidak melakukan pemupukan sebanyak dua kali seperti yang dianjurkan oleh PT Buma Cima Nusantara dan sebesar 66,67 persen petani tebu rakyat tidak menggunakan pupuk organik sebagai pupuk tambahan. Hal-hal tersebut dapat mempengaruhi rendahnya rendemen petani tebu rakyat di Kecamatan Bunga Mayang.

Keadaan pabrik yang sudah tua mengakibatkan pabrik terkadang mengalami kendala pada mesin, sehingga pabrik berhenti giling sampai mesin selesai diperbaiki dan tebu yang telah tertebang terpaksa harus menunggu. Batas waktu tunggu atau retensi $<24$ jam, jika lebih dari 24 jam akan menyebabkan tebu kehilangan banyak rendemen. Sebelum tebu diangkut dari lahan ke pabrik, pastikan tebu bersih dari kotoran seperti sogolan, pucukan, tanah, dan klaras karena tingginya 
kotoran akan meningkatkan potensi kehilangan gula dalam proses pengolahan di pabrik.

\section{Pola Kemitraan antara Petani Tebu Rakyat dengan PT Buma Cima Nusantara}

Pelayanan yang diberikan PT Buma Cima Nusantara kepada petani mitra antara lain, petani mitra memperoleh pinjaman dana sesuai dengan luasan lahan yang dimiliki. Pinjaman dana tersebut berupa biaya perawatan, biaya saprodi, dan biaya tebang muat angkut (TMA). Pinjaman dana tersebut dikenakan biaya bunga pinjaman sebesar tujuh persen untuk biaya perawatan dan biaya TMA, serta tiga persen untuk biaya bibit dan pupuk. Pembayaran bunga pinjaman dilakukan dengan cara memotong pendapatan yang diterima saat musim panen tiba, dan kebijakan ini sudah melalui persetujuan antara kedua belah pihak. Pinjaman dana disalurkan melalui ketua kelompok tani yang kemudian akan disalurkan kepada anggota kelompok tani.

Paket pinjaman untuk biaya bibit sebesar Rp4.400.000,00/ha. Paket pinjaman untuk biaya pupuk sebesar Rp4.290.000,00/ha. Paket pinjaman untuk TMA ditentukan sesuai dengan jumlah produksi tebu yang dihasilkan, yaitu Rp95.000,00/ton untuk Desa Mulyorejo II dan Rp107.500,00/ton untuk Desa Isorejo. Paket pinjaman untuk perawatan yang terdiri dari biaya pestisida dan TKLK selain TMA adalah Rp5.000.000,00/ha untuk kriteria PC dan Rp2.800.000,00/ha untuk kriteria keprasan.

Petani mitra juga memperoleh bimbingan teknis budidaya tebu dari pihak perusahaan. Bimbingan ini dilakukan dengan dua cara, yaitu secara formal dan non formal. Bimbingan secara formal dilakukan melalui forum resmi seperti pelatihan rutin tahunan atau penyuluhan, sedangkan bimbingan secara non formal dilakukan melalui kunjungan oleh pihak perusahaan yang bertugas di wilayah petani.

Perhitungan bagi hasil gula petani dan pabrik gula ditetapkan sebagai berikut: (1) jika rendemen sampai dengan 7,00 persen, maka pabrik gula menerima 34 persen gula yang dihasilkan dan petani menerima 66 persen gula yang dihasilkan dengan rumus, gula $=$ ton tebu $\times$ rendemen individu $(\mathrm{s} / \mathrm{d} 7,00 \%) \times$ faktor SHS $(1,003) \times 66 \%$, (2) jika rendemen lebih dari 7,00 persen, maka selisih kelebihan rendemennya pabrik gula menerima 32 persen gula yang dihasilkan dan petani menerima 68 persen gula yang dihasilkan dengan rumus, gula $=$ ton tebu $\times$ selisih kelebihan rendemen individu $(>7,00 \%) \times$ faktor SHS $(1,003)$ $\times 68 \%$, sehingga total gula petani $=$ gula (rendemen s/d 7,00\%) + gula (selisih rendemen > $7,00 \%)$. Perhitungan tetes milik petani ditetapkan sebesar tiga persen dikali ton tebu. Apabila terjadi kerusakan pada alat core sampler, maka perhitungan bagi hasil menggunakan rendemen rata-rata tebu sendiri dan tebu rakyat pada periode tersebut. Petani bersedia dibebani biaya karung plastik, inner bag, dan biaya asuransi tangki tetes sesuai ketentuan yang berlaku di PT Buma Cima Nusantara.

Berdasarkan hasil penelitian, seluruh petani tebu mitra di Kecamatan Bunga Mayang menyatakan sistem bagi hasil yang diterapkan oleh PT Buma Cima Nusantara sudah adil karena sudah sesuai dengan Surat Keputusan Menteri Negara Badan Usaha Milik Negara (BUMN) tentang bagi hasil TR No. S-361/MBN/2012 tanggal 13 Juli 2013. Menurut petani responden, besarnya persentase bagi hasil yang telah ditetapkan tidak merugikan bagi kedua belah pihak.

Seluruh petani tebu mitra menyatakan bahwa pembayaran hasil panen atau bagi hasil sudah tepat waktu, jika dibandingkan dengan tahun-tahun sebelumnya. Hal tersebut dikarenakan PT Buma Cima Nusantara telah menerapkan sistem terbaru, dimana rendemen petani dikeluarkan setiap hari. Tidak seperti tahun-tahun sebelumnya, rendemen petani dikeluarkan dua minggu atau satu periode sekali. Penerapan sistem terbaru tersebut dapat mempercepat proses terjualnya gula milik petani dan mempercepat pembayaran bagi hasil. Selain itu, pada musim tanam 2018/2019 penjualan gula TR dilakukan satu pintu atau partai besar tidak seperti tahun-tahun sebelumnya, sehingga proses penjualan gula dan bagi hasil juga menjadi lebih cepat.

Produksi gula 90 persen adalah jumlah 90 persen dari total produksi gula keseluruhan yang penjualannya dilakukan melalui perantara PT Buma Cima Nusantara dengan cara pelelangan gula, sedangkan produksi gula 10 persen adalah jumlah 10 persen dari total produksi gula keseluruhan yang dijual sendiri oleh petani tanpa menggunakan perantara PT Buma Cima Nusantara.

PT Buma Cima Nusantara berperan sebagai perantara dalam penjualan gula 90 persen dan tetes TR. Penjualan gula 90 persen dan tetes TR dilakukan melalui lelang. Sebelum dilakukan lelang, para petani membuat kesepakatan penjualan 
dilakukan satu pintu (partai besar) atau tidak. Setelah itu, PT Buma Cima Nusantara melaporkan jumlah produksi gula 90 persen dan tetes TR kepada pihak direksi. Pihak direksi melaporkan jumlah produksi tersebut kepada PT Kharisma Pemasaran Bersama Nusantara. Pembayaran hasil penjualan gula dan tetes TR dari pembeli dikirim melalui rekening PT Buma Cima Nusantara, kemudian dilakukan bagi hasil antara pihak petani dan pihak PT Buma Cima Nusantara. Harga jual gula 90 persen dan tetes pada musim tanam 2018/2019 adalah Rp10.200,00/kg dan $\mathrm{Rp} 1.300,00 / \mathrm{kg}$.

Berbeda dengan gula 90 persen, gula 10 persen diberikan oleh pihak perusahaan dalam bentuk natura kepada petani. Gula tersebut dijual petani dengan harga hasil kesepatakan antara masingmasing petani dan pembeli gula mereka. Biasanya, petani menjual gula 10 persen dengan harga yang lebih tinggi dari pada harga gula 90 persen karena penjualan dilakukan dalam jumlah kecil. Rata-rata harga jual gula 10 persen adalah Rp11.419,70/kg.

Hak petani mitra adalah (1) menerima bagi hasil gula dan perhitungan tetes, serta (2) diberikan tetes dalam bentuk natura sebanyak 3 persen $\times$ ton tebu. Kewajiban petani mitra adalah (1) menyiapkan lahan, (2) menjaga keamanan tanaman tebu kemitraan, (3) melakukan budidaya tebu kemitraan sesuai kultur teknis yang berlaku, (4) turut serta dalam sumbangan pemikiran, pengelolaan dan pemeliharaan tebu kemitraan, serta melaksanakan tebang angkut.

Hak pabrik gula antara lain, (1) memberi supervisi, pembinaan petunjuk teknis dalam persiapan pengolahan lahan, (2) mengatur dan mengkoordinasikan pelaksanaan tebang sesuai jadwal dan besarnya disesuaikan kapasitas giling, (3) turut serta menjaga keamanan tanaman tebu kemitraan, (4) membantu menetapkan sistem tanam, sistem kepras, dan tata cara kepras, (5) memberikan saran-saran yang diperlukan pihak petani dalam hal pengelolaan tebu kemitraan, (6) melarang pihak petani menjual, mengalihkan, menjaminkan, menggiling tanaman tebu kemitraan yang terkait perjanjian kepada pihak lain, (7) mendapatkan hak bagian hasil produksi, (8) memotong hasil penjualan dari hasil produksi gula bagian pihak petani untuk melunasi pinjaman modal kerja (KUR dan PKBL), serta (9) menerima pembayaran hasil penjualan gula dan tetes petani dari pembeli melalui rekening PT Buma Cima Nusantara. Kewajiban pabrik gula antara lain, (1) memberikan bimbingan teknis kepada pihak petani, (2) bertindak sebagai avalis off taker kredit KUR dan PKBL pihak petani, serta penjamin pasar, (3) membagi hasil produksi gula kepada pihak petani sesuai ketentuan yang berlaku, (4) menyalurkan pinjaman modal kerja yang berasal dari kreditur kepada pihak petani, (5) menggiling seluruh hasil produksi tanaman tebu kemitraan, dan (6) memberikan fasilitas untuk memanfaatkan gudang milik pihak pabrik gula.

Berdasarkan hasil penelitian, kendala yang dihadapi oleh pihak perusahaan dalam pelaksanaan program kemitraan adalah sulitnya melakukan monitoring terhadap jumlah dana yang disalurkan ketua kelompok tani kepada petani kepada petani, karena untuk menyalurkan dana secara langsung kepada petani memerlukan proses administrasi yang cukup rumit bagi pihak perusahaan, mengingat banyaknya petani tebu rakyat yang bermitra dengan PT Buma Cima Nusantara. Kendala lain yang dihadapi oleh pihak perusahan adalah administrasi proses pencairan dana dari penyandang dana atau pihak ketiga terbilang rumit, sehingga penyaluran modal terhambat. Hal tersebut dikarenakan petani belum begitu memahami mengenai pesyaratan administrasi yang harus mereka selesaikan.

Sebesar 42,42 persen petani tebu mitra menyatakan belum puas terhadap kinerja PT Buma Cima Nusantara. Beberapa hal yang menyebabkan petani merasa belum puas antara lain, mesin pengolahan pada pabrik yang mengalami kerusakan pada saat musim giling, kurangnya transparansi terkait rendemen aktual yang diterima oleh masing-masing petani, kegiatan penyuluhan dan monitoring ke lapangan oleh pihak perusahaan dirasa masih kurang, dan terdapat beberapa jalan menuju pabrik yang rusak.

Berdasarkan hasil penelitian, bentuk kemitraan yang dilaksanakan antara PT Buma Cima Nusantara dengan petani tebu mitra adalah pola kemitraan kerjasama operasional agribisnis (KOA). Pola kemitraan KOA merupakan pola hubungan bisnis yang dijalankan oleh kelompok mitra dan perusahaan mitra. Petani tebu rakyat berperan sebagai kelompok mitra, dimana kelompok mitra menyediakan lahan, sarana, dan tenaga kerja. PT Buma Cima Nusantara berperan sebagai perusahaan mitra, dimana perusahaan mitra menyediakan biaya, modal, manajemen, dan pengadaan sarana produksi untuk mengusahakan atau membudidayakan suatu komoditas pertanian yang mana dalam hal ini adalah tebu. Selain itu, perusahaan mitra juga berperan sebagai penjamin 
pasar produk dengan meningkatkan nilai tambah produk melalui pengolahan dan pengemasan. Hasil penelitian ini selaras dengan hasil penelitian Sixmala, Antara, dan Suamba (2019) yang menyatakan bahwa pola kemitraan yang terjalin antara Pabrik Gula Rejo Agung Baru dengan petani tebu adalah Kerjasama Operasional Agribisnis (KOA). Kemitraan ini melakukan sistem bagi hasil yang ditentukan dari rendemen tebu yang diperoleh petani.

\section{KESIMPULAN}

Pendapatan per hektar per musim tanam atas biaya tunai usahatani tebu rakyat seluruh kriteria di Kecamatan Bunga Mayang, Kabupaten Lampung Utara adalah sebesar Rp19.276.494,71 dengan R/C rasio sebesar 2,04 dan pendapatan per hektar per musim tanam atas biaya total sebesar Rp12.056.030,40 dengan R/C rasio sebesar 1,49. Bentuk kemitraan yang dilaksanakan antara PT Buma Cima Nusantara dengan petani tebu mitra di Kecamatan Bunga Mayang adalah pola kemitraan Kerjasama Operasional Agribisnis (KOA), dimana petani tebu rakyat berperan sebagai kelompok mitra yang menyediakan lahan, sarana, serta tenaga kerja dan PT Buma Cima Nusantara berperan sebagai perusahaan mitra yang menyediakan biaya, modal, manajemen, pengadaan sarana produksi, serta menjadi penjamin pasar produk.

\section{DAFTAR PUSTAKA}

Agiesta V, Widjaya S, dan Hasanuddin T. 2017. Faktor-faktor yang berhubungan dengan keputusan petani beralih kemitraan dalam berusahatani: kasus petani kemitraan tebu di PT Gunung Madu Plantations beralih ke kemitraan ubi kayu di Pabrik Bumi Waras. Jurnal Ilmu Ilmu Agribisnis, 5 (1): 93-100. http://jurnal.fp.unila.ac.id/ index.php/JIA/article/viewFile/1679/1505. [4 November 2019]

Apriawan DC, Irham, dan Mulyo JH. 2015. Analisis produksi tebu dan gula di PT Perkebunan Nusantara VII (Persero). Agro Ekonomi, 26 (2): 159-167. https://journal. ugm.ac.id/jae/article/view/17268. [12 Juni 2020].

Arifin B. 2008. Ekonomi Swasembada Gula Indonesia. Economic Review. No. 211, Maret 2008. https://www.researchgate.net/profile/ bustanul_arifin2/publication/240631517_ekon omi_swasembada_gula_indonesia/links/59562 153aca272fbb37d14bc/ekonomi-swasembadagula-indonesia.pdf. [22 Desember 2019].
Badan Penelitian dan Pengembangan Pertanian. 2007. Prospek dan Arah Pengembangan Agribisnis Tebu (Edisi Kedua). Departemen Pertanian. Jakarta.

Direktorat Jendral Perkebunan. 2018. Produksi Tebu Menurut Provinsi di Indonesia, 20152018. https://www.pertanian.go.id/home/ index.php?show=repo\&fileNum=211. $\quad[13$ Oktober 2019].

2018. Luas Areal Tebu Menurut Provinsi di Indonesia, 20152018. https://www.pertanian.go.id/home/ index.php?show $=$ repo \&fileNum $=223$. Oktober 2019].

Gustiana E. 2017. Analisis Pendapatan dan Distribusi Pendapatan Usahatani Tebu Rakyat di Kecamatan Bunga Mayang, Kabupaten Lampung Utara. Skripsi. Jurusan Agribisnis Universitas Lampung. Bandar Lampung.

Nazir M. 1988. Metode Penelitian. Ghalia Indonesia. Jakarta.

Pranoto IL, Lestari DAH, dan Murniati K. 2017. Evaluasi kemitraan antara petani tebu dan PT Perkebunan Nusantara VII Unit Usaha Bunga Mayang, Kecamatan Bunga Mayang, Kabupaten Lampung Utara. Jurnal Ilmu Ilmu Agribisnis, 5 (4): 376-383. http://jurnal.fp.unila.ac.id/index.php/JIA /article/view/1746/1549. [7 Oktober 2019].

PT Buma Cima Nusantara. 2019. Rencana Kerja dan Anggaran Perusahaan 2020. PT Buma Cima Nusantara. Bunga Mayang.

Sakinah AF, Hasyim AI, dan Suryani S. 2019. Pendapatan rumah tangga petani tebu mitra mandiri di PT PSMI, Kabupaten Way Kanan. Jurnal Ilmu Ilmu Aagribisnis, 7 (4): 436-442. https://jurnal.fp.unila.ac. id/index.php/JIA/article/view/3857/2825 . [13 Mei 2020].

Sixmala M, Antara M, dan Suamba IK. 2019. Peran kemitraan agribisnis petani tebu dengan Pabrik Gula Rejo Agung Baru, Madiun, Jawa Timur. Jurnal Agribisnis dan Agrowisata, 8 (3): 311-320. https://ojs.unud.ac.id/index.php/ JAA/article/view/54718. [12 Juni 2020].

Soekartawi. 2002. Analisis Usahatani. UI-Press. Jakarta.

Sugiarto, Siagian D, Sunaryanto LT, dan Oetomo DS. 2003. Teknik Sampling. Gramedia Pustaka Utama. Jakarta.

Sumardjo, Sulaksana J, dan Darmono WA. 2004. Teori dan Praktik Kemitraan Agribisnis. Penebar Swadaya. Jakarta.

Supriyadi A. 1992. Rendemen Tebu: Liku-Liku Permasalahannya. Kanisius. Yogyakarta. 